\title{
PENINGKATAN PROSES PEMBELAJARAN TEMATIK DENGAN MODEL ACCELERATED LEARNING DI KELAS III SD NEGERI 18 SINAPA PILIANG KEC. LUBUK SIKARAH KOTA SOLOK
}

\author{
Riri Kartika \\ Surel: arkhatika89@yahoo.com
}

\begin{abstract}
This research was aimed at improving the students' thematic learning by using accelerated learning model in class III of SDN 18 Sinapa Piliang Kota Solok. The result of the research indicated that, In the first cycle, the average score of the students on the six lessons was 73.88 for which they were in adequate category (the average score was between (65-80\%), this then improved into 79,35 in the second cycle for which they were in adequate category (the average score was between 65-80\%). In the third cycle, their average score improved into 83 for which they were in good category (the average score was between 80-100\%). The learning process conducted by the teacher improved from 72,1 in the first cycle into 80,55 in the second cycle, and it became 90,5 in the third cycle. Meanwhile, the students' aspect improved from 73 in the first cycle into 78 in the second cycle, and it became 89 in the third cycle. Based on these result, it was concluded that the thematic learning could be improved by using accelerated learning model.
\end{abstract}

Keywords : Accelerated learning, Learning model, Thematic learning

\section{PENDAHULUAN}

Dunia pendidikan telah mengalami berbagai kemajuan yang pesat di era globalisasi ini. Kemajuan tersebut tidak terlepas dari berbagai usaha yang dilakukan baik oleh praktisi, pengamat, maupun pemerintah untuk ketercapaian pendidikan yang optimal. Usaha yang dilakukan dalam peningkatan pendidikan yaitu dengan merancang sistem pembelajaran yang disesuaikan dengan perkembangan dan kebutuhan peserta didik khususnya pendidikan pada jenjang Sekolah Dasar (SD) yang berada pada tahap perkembangan operasional konkrit. Peserta didik pada tahap operasional konkrit mengalami perkembangan yang sangat luar biasa. Pada tahapan tersebut peserta didik memahami sesuatu berdasarkan hal yang bersifat nyata. Selain itu, pada masa perkembangan tersebut umumnya peserta didik masih melihat segala sesuatu sebagai satu keutuhan (holistik) dan memahami hubungan antara konsep secara sederhana. Untuk itu, pembelajaran pada jenjang SD dilaksanakan dengan pembelajaran yang bersifat holistik.

Pelaksanaan Pembelajaran yang bersifat holistic, peserta didik tidak hanya dapat mengembangkan kemampuan aspek kognitif saja melainkan mampu mengembangkan aspek afektif dan psikomotor. Selain itu, dengan pembelajaran holistik 
dapat mengembangkan kemampuan berpikir kritis, kreatif, dan reflektif. (Nanik dan Dany, 2010:123).

Selain itu, agar guru mengetahui konsep yang dipahami peserta didik, guru hendaknya merancang pembelajaran yang memberikan banyak kesempatan kepada peserta didik untuk aktif mengemukakan pendapatan atau gagasannya. Dengan kata lain, pembelajaran mengembangkan keterampilan komunikasi peserta didik. Keterampilan komunikasi tersebut diperlukan untuk mengetahui sejauh mana konsep yang dipahami peserta didik agar mudah memasukan konsep baru yang lebih relevan.

Untuk memasukkan konsep baru kepada peserta didik, guru hendaknya merancang pembelajaran yang optimal dan menyenangkan. Hal tersebut diwujudkan dengan menciptakan lingkungan belajar yang positif bagi peserta didik untuk belajar dan memperhatikan cara belajar (visual, auditori, dan kinestetik) yang sesuai dengan dirinya. Hal ini bertujuan agar peserta didik dapat dengan mudah menyerap informasi yang diberikan. Selain itu, juga perlu pemanfaatan berbagai sumber belajar untuk menciptakan suasana belajar yang menyenangkan.

Melihat karakteristik dan kebutuhan peserta didik tersebut pemerintah perlu mengupayakan pelaksanaan pendidikan yang ideal. Pelaksanaan pendidikan yang ideal diharapkan mampu mengoptimalkan pembelajaran agar tujuan utama pendidikan yaitu menjadikan peserta didik yang berkompetensi dapat tercapai. Maka pembelajaran yang cocok digunakan dengan melihat sesuatu secara nyata, holistik dan bermakna adalah pembelajaran tematik.

Rusman

berpendapat "Pembelajaran tematik merupakan salah satu model dalam pembelajaran terpadu yang merupakan suatu sistem pembelajaran yang memungkinkan peserta didik baik secara individual maupun kelompok, aktif menggali dan menemukan konsep serta prinsipprinsip keilmuan secara holistik, bermakna, dan autentik".

Pembelajaran tematik merupakan pembelajaran yang memberikan kesempatan bagi peserta didik aktif dalam membangun, menggali, dan menemukan konsep pengetahuan secara holistik dan bermakna. Pelaksanaan pembelajaran tematik sendiri didasarkan pada tema tanpa adanya pemisahan antar mata pelajaran. Tanpa adanya pemisahan mata pelajaran tersebut maka pembelajaran tematik dapat dilaksanakan secara holistik dan bermakna bagi peserta didik.

Pembelajaran yang dilaksanakan dengan menggunakan pembelajaran tematik memiliki beberapa keuntungan. Senada dengan itu, Suryosubroto (2011:136-137) berpendapat pelaksanaan pembelajaran tematik memiliki 
beberapa kelebihan yaitu: (1) menyenangkan karena bertolak dari minat dan kebutuhan peserta didik, (2) pengalaman dan kegiatan belajar relevan dengan tingkat perkembangan dan kebutuhan peserta didik, (3) hasil belajar akan bertahan lebih lama karena lebih berkesan dan bermakna, dan (4) menumbuhkan keterampilan sosial seperti bekerja sama, komunikasi, dan tanggap terhadap gagasan orang lain.

Berdasarkan observasi yang dilakukan di kelas III SDN 18 Sinapa Piliang Kecamatan Lubuk Sikarah Kota Solok pada tanggal 17 April terlihat bahwa guru kurang melaksanakan pembelajaran tematik secara efektif. Hal tersebut terlihat dari masih adanya daftar pelajaran dan buku-buku yang masih dikemas perbidang studi. Seharusnya pembelajaran tematik dilaksanakan tanpa ada pemisahan antar bidang studi.

Selain itu, berdasarkan wawancara dengan guru di sekolah tersebut didapatkan informasi tentang keluhan guru terhadap pembelajaran tematik. Pembelajaran tematik yang dilaksanakan di sekolah tersebut juga belum menggunakan model atau strategi yang menunjang proses pembelajaran tematik yang tepat dan optimal. Pembelajaran masih dilaksanakan secara konvensional, yaitu hanya sebatas penyampaian informasi kepada peserta didik. Dalam pemerolehan pengetahuan guru juga kurang melibatkan informasi yang dimiliki peserta didik. Guru sering memberikan materi berdasarkan indikator yang akan dicapai dan kurang mengaitkannya dengan kehidupan nyata peserta didik atau konfirmasi dari pengalaman yang dialaminya. Setelah itu, kegiatan pembelajaran dilanjutkan dengan membuat latihan dari materi yang telah disampaikan.

Kegiatan pembelajaran yang demikian membuat pembelajaran terkesan monoton, membosankan, dan sulit mencapai pemahaman yang diharapkan. Hal tersebut dikarenakan informasi atau materi kurang dikaitkan dengan kehidupan nyata peserta didik. Keaktifan peserta didik dalam pembelajaran masih tergolong rendah karena pembelajaran kurang menunjang kegiatan aktif, komunikatif, dan interaktif peserta didik. Peserta didik tidak banyak diberikan kesempatan mengungkapkan gagasannya apalagi memberikan komentar terhadap gagasan yang didengarnya. Akibatnya, keterampilan komunikasi peserta didik masih tergolong rendah.

Pembelajaran yang menyenangkan, mengesankan, dan bermakna juga kurang diupayakan oleh guru. Media pembelajaran yang dapat digunakan sebagai penunjang proses pembelajaran dibuat kurang menarik perhatian peserta didik. Bahkan penyajian materi tertentu yang membutuhkan media tidak disediakan guru dengan berbagai alasan. Sehingga kekuatan visual, 
auditori, dan kinestetis yang diharapkan dari penggunaan media pembelajaran menjadi kurang berkembang.

$$
\text { Permasalahan yang }
$$

dikemukakan di atas perlu segera diatasi, agar dampak pembelajaran tersebut tidak semakin luas. Untuk itu, guru hendaknya merancang pembelajaran tematik sebaik mungkin dengan mempertimbangkan aspek perkembangan dan kebutuhan belajar peserta didik. Hal tersebut dapat dilaksanakan dengan mengikuti karakteristik, prinsip, dan ramburambu pembelajaran tematik yang dipadukan dengan rancangan model pembelajaran yang inovatif, menyenangkan, dan bermakna bagi aktivitas belajar peserta didik. Salah satu model pembelajaran yang inovatif, menyenangkan dan bermakna bagi peserta didik tersebut adalah model Accelarated Learning.

Model Accelarated Learning ini menekankan proses pembelajaran dengan lingkungan yang menyenangkan. Pembelajaran dilakukan dengan lingkungan yang menyenangkan maka pemasukan informasipun akan terasa sangat mudah untuk diserap dan dipahami oleh peserta didik. Pemasukan infomasipun juga dikaitkan dengan kehidupan nyatanya dan memungkinkan peserta didik untuk dapat mengemukakan ide dan gagasannya baik dalam bentuk lisan maupun tulisan yang berguna untuk meningkatkan kemampuan berkomunikasinya. Aktivitas tersebut digunakan guru untuk mengetahui sejauh mana pemahaman peserta didik terhadap suatu materi. Peserta didik dapat dikatakan paham apabila ide dan gagasannya dapat dipahami oleh orang lain.

Hal ini sejalan dengan pendapat Rose dan Nicholl (2009:35) yang menyatakan Accelarated Learning adalah sebuah model pembelajaran yang mengakui bahwa masing-masing dari peserta didik memiliki cara belajar pribadi pilihannya yang cocok dengan karakter dirinya. Ketika peserta didik belajar menggunakan model yang cocok dengan gaya belajar pribadinya, peserta didik dapat belajar dengan cara paling alamiah bagi diri anda sendiri. Sebab, yang alamiah manjadi lebih mudah dan yang lebih mudah menjadi lebih cepat itulah yang dimaksud dengan cara belajar cepat.

Model Accelarated Learning menekankan pada proses mendapatkan keadaan pikiran yang benar dalam pembelajaran dan menggali informasi tentang materi dari peserta didik berdasarkan pengamalan atau informasi yang diketahuinya. Pengetahuan tersebut selanjutnya dianalogikan untuk menanamkan konsep baru, Lalu dilanjutkan dengan kegiatan memicu memorinya dari hal-hal yang peserta didik pahami dari kegiatan presentasi untuk mengemukakan apa yang peserta didik pahami. Dan diakhiri 
dengan kegiatan refleksi dari

dilaksanakan.

Penggunaan

Model

Accelarated Learning dalam pembelajaran memiliki beberapa keuntungan. Lif, dkk (2011:12) menyatakan "Implementasi Accelerated Learning memberikan beberapa keuntungan yaitu: 1) menciptakan imajinasi dan kreatif peserta didik, 2) membuat peserta didik terlibat total, 3) menciptakan lingkungan belajar yang sehat, 4) mempercepat dan memperkaya belajar, 5) meningkatkan daya ingat dan peforma, 6) mempercepat proses rancangan belajar, 7) membangun masyarakat belajar yang efektif, dan 8) meningkatkan penggunaan teknologi dalam pembelajaran".

Model Accelerated Learning juga dinilai tepat dan sesuai dengan harapan pembelajaran yang bermakna. Hal tersebut dikarenakan pembelajaran dengan model Accelerated Learning ini melibatkan peserta didik dalam membangun pengetahuannya dan aktivitas pembelajaran mendukung keaktifan, kreativitas, dan kebermaknaan dengan cara yang menyenangkan. Dan diharapkan dapat meningkatkan mutu dan kualitas pembelajaran.

$$
\text { Model pembelajaran }
$$

accelerated learning yang dipilih pada penelitian ini adalah model pembelajaran accelerated menurut Rose dan Niccoll. Rose dan Niccoll (2009:94-97) berpendapat “Ada enam langkah pembelajaran dalam Accelerated Learning yang disingkat dengan MASTER. Langkah Accelerated Learning tersebut yaitu: (1) memotivasi pikiran peserta didik, (2) menggali fakta-fakta, (3) mencari makna, (4) memicu memori, (5) memamerkan apa yang diketahui peserta didik, dan (6) merefleksikan proses".

Kegiatan yang dapat dilakukan pada langkah memotivasi pikiran peserta didik adalah dengan membuka schemata peserta didik dari lagu atau gambar yang diamatinya, menyemapiakan tujuan pembelajaran, dan kegiatan mendemonstrasikan moto kelas untuk memberikan sugesti kepada peserta didik untuk suksesdalam pembelajaran dengan menyajikannya dalam bentuk yel-yel. Kegiatan tersebut berguna agar pikiran peserta didik terbuka terhadap materi pembelajaran yang akan diterimanya dengan cara yang menarik dan menyenangkan.

Kegiatan menggali fakta-fakta merupakan kegiatan menggali pengetahuan peserta didik berdasarkan apa yang dialami, dilihatnya,dan didengarnya. Sehingga apa yang dipahaminya dapat diketahui oleh guru dengan baik. Hal tersebut dapat dilakukan dengan meminta peserta didik menceritakan pengalamannya dan mendeskripsikan gambar yang diamatinya guna mengingatkannya kemabali terhadap pengalamannya yang berkesan. 
Selanjutnya kegiatan mencari makna bertujuan untuk memasukan pengetahuan baru kepada peserta didik. Pengetahuan tersebut didapatkan dengan memberikan teks bacaan yang berkaitan dengan subtema yang dipilih, Selain itu, kegiatan seperti menggambar dan menulis menambah kebermakanaan pengetahuan yang didapatkan sehingga pengetahuan baru yang diterimanya diperoleh dengan cara yang menarik dan menyenagkan yang melibatkan kekuatan visual, audio, dan kinestetis dengan seimbang.

Kegiatan pada langkah memicu memori berguna untuk mengingatkan peserta didik terhadap apa yang telah didapatkan dengan kegiatan menulis, mengerjakan lembar kerja, dan menyusun puzlee kegiatan ini dipilih dengan cara yang menarik dan menyenagkan dan memperhatikan ketiga kekuatan belajar peserta didik.

Selanjutnya pada kegiatan memamerkan apa yang diketahui peserta didik berguna untuk mengetahui apa yang telah dipahami peserta didik. Bila peserta didik dapat menjelaskan dan penjelasannya tersebut juga dapat dipahami maka hal tersebut menunjukan peserta didik memahami pelajaran yang diberikan. Kegiatan ini dilakukan dengan kegiatan mempresentasikan lembar kerja yang dibuat, menaggapi penjelasan, dan mendiskusikan jawaban yang didapatkan.
Kegiatan diakhiri dengan merefleksikan proses yang berguna untuk memberikan penguatan dan klarifikasi terhadap apa yang telah disampaikandan dipahami peserta didik. Kegiatan pada langkah ini dilakukan dengan memberikan komentar terhadap presentasi peserta didik, merangkum pembelajaran, mengulas materi yang kurang dipahami peserta didik, dan menyimpulkan pembelajaran.

\section{METODE PENELITIAN}

Jenis penelitian yang dilakuan dalam penelitian ini adalah penelitian tindakan kelas (PTK). Rancangan ini dipilih karena dpaat memperbaiki proses pembelajaran tematik sesuai dengan tujuan penelitian ini, yaitu meningkatakan proses pembelajaran tematik di kelas III SD. Penelitian ini menggunakan pendekatan kualitatif. menurut Kemmis dan Taggart (1988:5) "Action research is a form of collective self reflective enquiry undertal en by participants in social situations in order to improve the rationally and justice of their own social or educational practices, as well as their inderstanding of these practices and the situations in which these practices are carried out."

Penelitian ini dilaksanakan di kelas III SDN 18 Sinapa Piliang Kecamatan Lubuk Sikarah Kota Solok. Peneliti bertindak sebagai observer. Subjek dalam penelitian ini adalah guru dan peserta didik yang berjumlah 18 orang yang terdiri dari 7 
peserta didik perempuan dan 11 orang peserta didik laki-laki di kelas III SD terteliti. Peserta didik tersebut terdaftar sebagai peserta didik kelas III tahun ajaran 2013-2014. Penelitian dilakukan dalam 3 siklus. pada siklus I waktu yang dibutuhkan adalah 3 kali pertemuan. Sedangkan pada siklus II dan III dibutuhkan 2 kali pertemuan.

Penelitian ini dirancang dengan prosedur penelitian yang meliputi langkah: perencanaan, pelaksanaan, pengamatan, dan refleksi. Rancangan penelitian tersebut dilaksanakan dalam bentuk alur penelitian. Alur penelitian tersebut dilaksanakan sesuai dengan prosedur penelitian yang digunakan.

Data penelitian ini dikumpulkan dengan menggunakan pencatatan lapangan, observasi, dokumentasi, wawancara, dan lembar penilaian. Setelah data terkumpul peneliti melakukan analisis data. Menurut Masnur (2009:91) “Analisis data pada dasarnya adalah upaya memilih, memilah, membuang, dan menggolongkan data". Tahap analisi data tersebut dilakukan dengan kegiatan: 1) menelaah data, 2) reduksi data, 3) menyajikan data, 4) dan menyimpulkan hasil penelitian.

\section{HASIL DAN PEMBAHASAN Siklus I}

Siklus I ini dikembangkan dengan tema pengalaman subtema berlibur. Subtema yang digunakan tersebut terlihat dari penggunaan media, teks bacaan dan masalah dikembangkan. Kegiatan tersebut diawali dengan kegiatan peserta didik menyanyikan lagu pergi tamasya. Selanjutnya peserta didik membahas isi lagu sampai dengan menceritakan pengalaman tentang pengalamann berliburnya. Media yang digunakan pada siklus I ini adalah gambar berbagai bentuk objek wisata yang terdapat didaerahnya. Hal ini bertujuan untuk memudahkan peserta didik untuk mengingat pengalaman liburannya.

Berdasarkan penilaian hasil belajar yang dilakukan pada enam bidang studi yaitu: bahasa Indonesia, IPA, IPS, PKn, Matematika, dan SBK diperoleh hasil pembelajaran tematik. hasil pembelajaran dengan menentukan nilai rata-rata ke enam bidang studi. Rata-rata hasil belajar secara klasikal adalah 74.1 dengan kualifikasi cukup. Sedangkan nilai ketuntasan secara klasikalt diperoleh sebanyak 10 peserta didik atau sebesar 59\% tidak berhasil mencapai nilai ketuntasan. Sedangkan sebanyak 7 peserta didik atau sebesar $41 \%$ berhasil mencapai nilai ketuntasan dari ketuntasan nilai minimal sebesar 75,00. Berdasarkan hasil tersebut disimpulkan bahwa secara klasikal peserta didik belum mencapai ketuntasan.

\section{Siklus II}

Siklus II ini dikembangkan dengan tema pengalaman subtema bermain. Subtema yang digunakan tersebut terlihat dari penggunaan 
media, teks bacaan dan masalah dikembangkan. Kegiatan tersebut diawali dengan kegiatan peserta didik menyanyikan lagu bermain layanglayang. Selanjutnya peserta didik membahas isi lagu sampai dengan menceritakan pengalaman tentang bermain. Media yang digunakan pada siklus II ini adalah gambar berbagai bentuk permainan yang disenangi peserta didik.

Setelah itu, peserta didik membaca teks bacaan tentang kegiatan bermain. Dari bacaan tersebut peserta didik melakukan berbagai kegiatan berdasarkan teks bacaan yang telah dibaca diantaranya, menggambar, menulis karangan, dan menyelesaikan permasalahan yang berkaitan dengan teks bacaan tentang pengalaman bermain. Bentuk penilaian yang dilakukan juga berkaitan dengan subtema bermain dan dikemas dalam bentuk yang lebih menyenangkan sehingga hasil belajar dapat meningkat dari siklus sebelumnya.

Berdasarkan penilaian hasil belajar yang dilakukan pada enam bidang studi yaitu: bahasa Indonesia, IPA, IPS, PKn, matematika, dan SBK diperoleh hasil pembelajaran tematik. Hasil pembelajaran dengan menentukan nilai rata-rata pada enam bidang studi. Rata-rata hasil belajar tematik secara klasikal adalah 79.5. Perolehan hasil belajar tersebut telah mencapai nilai ketuntasan namun masih dalam kualifikasi cukup. Sedangkan ketuntasan peserta didik secara klasikal diperoleh sebanyak 3 peserta didik atau sebesar $18 \%$ tidak berhasil mencapai nilai ketuntasan.. Sedangkan sebanyak 14 peserta didik atau sebesar $82 \%$ berhasil mencapai nilai ketuntasan dari ketuntasan nilai minimal sebesar 75,00. berdasarkan hasil tersebut disimpulkan bahwa secara klasikal peserta didik telah mencapai ketuntasan.

\section{Siklus III}

Siklus III ini dikembangkan dengan tema pengalaman subtema merayakan HUT RI. Subtema ini diambil untuk menanampkan semangat nasionalismenya dengan pengalamannya tentang perayaan HUT RI. Subtema yang digunakan tersebut terlihat dari penggunaan media, teks bacaan dan masalah dikembangkan. Kegiatan tersebut diawali dengan kegiatan peserta didik menyanyikan lagu hari merdeka disertai video klip lagu tersebut. Selanjutnya peserta didik membahas isi lagu sampai dengan menceritakan pengalaman tentang merayakan HUT RI. Media yang digunakan pada siklus II ini adalah gambar berbagai bentuk kegiatan yang umumnya dilakukan dalam perayaan tersebut khususnya berbagai perlombaan.

Berdasarkan penilaian hasil belajar yang dilakukan pada enam bidang studi yaitu: bahasa Indonesia, IPA, IPS, PKn, matematika, dan SBK diperoleh hasil pembelajaran tematik. hasil pembelajaran dengan menentukan nilai rata-rata keenam 
bidang studi. rata-rata hasil belajar secara klasikal adalah 86,5 . Perolehan hasil belajar tersebut telah mencapai nilai ketuntasan dan telah mencapai kualifikasi baik. Sedangkan ketuntasan peserta didik secara klasikal diperoleh sebanyak 1 peserta didik atau sebesar 6\% tidak berhasil mencapai nilai ketuntasan.. Sedangkan sebanyak 16 peserta didik atau sebesar $94 \%$ berhasil mencapai nilai ketuntasan dari ketuntasan nilai minimal sebesar 75,00. Berdasarkan hasil tersebut disimpulkan bahwa secara klasikal peserta didik telah mencapai ketuntasan.

\section{KESIMPULAN}

Penggunaan model Accelerated Learning dapat meningkatkan Pembelajaran tematik di kelas III SDN 18 Sinapa Piliang Kota Solok. Peningkatan pembelajaran tematik dengan model Accelerated Learning terjadi pada proses pembelajaran yang dilakukan guru maupun peserta didik. Hal ini terlihat dari hasil pengamatan yang observer lakukan saat proses pembelajaran yang dilakukan guru. Pada siklus I hasil pengamatan menunjukan keberhasilan pembelajaran adalah 72.1, pada siklus II 80.55, dan pada siklus III meningkat menjadi 90.5. Peningkatan proses pembelajaran tematik yang dilakukan peserta didik juga terjadi peningkatan. Peningkatan proses pembelajaran tersebut diketahui dari hasil lembar pengamatan. Pada siklus I menunjukan keberhasilan pembelajaran dari 72.1 pada siklus I, 80.55 pada siklus II, dan pada siklus III meningkat menjadi 90.5.

Peningkatan pembelajaran juga terjadi pada hasil belajar pembelajaran tematik terhadap enam bidang studi yang dilakukan. Hasil belajar diperoleh dari penghitungan nilai rata-rata hasil belajar pada enam mata pelajaran yang digunakan yaitu bahasa Indonesia, IPA, IPS, PKn, matematika, dan SBK. Hasil belajar yang diperoleh pada siklus I adalah 74.1, pada siklus II 79.5, dan pada siklus III meningkat menjadi 86.5.

Berdasarkan kesimpulan di atas, adapun saran dari peneliti ialah:

1. Disarankan agar guru perlu melakukan aktivitas memotivasi pikiran peserta didik ketika akan memulai pembelajaran, agar peserta didik dapat termotivasi untuk belajar melalui aktivitas yang menyenangkan seperti menyampain tujuan pembelajaran, membangkitkan skemata peserta didik, dan membuat moto kelas.

2. Agar guru mengupayakan pembelajaran dengan aktivitas yang bermakna dan menyenangkan bagi sehingga peserta didik mendapatkan pengetahuan secara efektif.

3. Agar guru menggunakan kekuatan auditori, visual, dan kinestetis untuk memingkatkan keaktifan dan motivasi belajar peserta didik sehingga 
Riri Karika: Peningkatan Proses Pembelajaran ..

pembelajaran lebih mudah dipahami dan dimengerti.

4. Agar guru melakukan penilaian dengan cara yang lebih menyenagkan dan sesuai dengan karakteristik belajar sambil bermain peseta didik namun tidak mengurangi kualitas hasil yang didapatkan. Seperti kegiatan bercerita, menyusun puzzle, menggambar, mengerjakan lembar kerja dengan tampilan yang menarik minat peserta didik untuk mengerjakan penilaian secara tidak langsung.

\section{DAFTAR RUJUKAN}

Kemmis dan Taggart. 1988. The Action Research Planner. Victoria: Deakin University Prees.

Lif, dkk. 2011. Pembelajaran Akselerasi. Jakarta: Prestasi Pustaka.

Masnur, $\quad 2009$. Melaksanakan Penelitian Tindakan Kelas Itu Mudah. Jakarta: Bumi Aksara.

Nanik dan Dany. 2010. Strategi Pembelajaran Holistik di Sekolah. Prestasi Pustaka: Bandung.
Rose dan Nicholl. 2009. Accelerated Learning: For The 21 Century Cara Belajar Cepat Abat XXI. Bandung: Nuansa.

Rusman. 2012. Model-Model Pembelajaran Mengembangkan Professional Guru. Jakarta: Raja Grafindo Persada.

Suryosubroto. 2011. Proses Belajar Mengajar di Sekolah. Jakarta: Rineka Cipta. 